\title{
Interference of speed at cutting height and damage to rootstock in mechanical harvesting of sugarcane
}

\author{
Murilo Battistuzzi Martins*, João Vitor Paulo Testa, Fernanda Scaranello Drudi, Jefferson Sandi, Carlos \\ Renato Guedes Ramos, Kléber Pereira Lanças
}

\author{
Universidade Estadual Paulista - UNESP - Campus Botucatu/SP, Brazil \\ Universidade Federal Rural da Amazônia - UFRA - Campus de Tomé-Açu/PA, Brazil
}

\begin{abstract}
In the mechanized harvest, the quality of the basal cut becomes one of the most important factors because it is associated with sprouting of the cane field. The objective of this work was to evaluate the influence of speed at cutting height and damage to the rootstock in function of mechanized harvesting of sugarcane. The variety used was CTC 15, with an average yield of $92.5 \mathrm{t}$ ha-1. The mechanized harvest was conducted without previous burning of the cane field, in an area with a slope of $6 \%$ and a spacing of 1.5 meters between rows of planting. Three speeds were selected for movement of the harvester: V1: 3.0, V2: 5.0 and V3: $7.0 \mathrm{~km} \mathrm{~h}^{-1}$, performed with four replications. The evaluation of the quality of the mechanized harvest in relation to the basal cut was determined with the evaluation of the remaining stumps and the damages caused to rootstocks after the passage of the harvester. The height of cut was measured with a tape measure. For the damages to rootstocks, the chi-square test was applied. The cut height measurements were submitted to ANOVA and the averages were analyzed by Tukey test at $5 \%$ probability. The results showed that increase in speed during the operation of mechanized harvesting of sugarcane increased the average height of cut in evaluated treatments, as well as the damages to rootstocks which was higher according to the increase in the speed of the harvester. The increase in the speed of displacement of the sugarcane harvester influenced the height of the cut and the damage to the rootstock.
\end{abstract}

Keywords: Saccharum spp, Quality, Mechanization.

\section{Introduction}

Brazil is considered the world's largest producer of sugarcane. This crop is of great importance to Brazilian agribusiness. From the entire sugarcane production area, the Southeast represents $63 \%$ of the total area harvested (Conab, 2017). Mechanized harvesting of the sugarcane crop has become necessary in every country due to environmental laws, lack of labor, increased productivity due to the increase in sugarcane production, as well as the better performance of the harvester (Giachini et al., 2016). Among all characteristics of the mechanized harvesting system, the quality of the basal cut becomes one of the most important because it is associated with the sprouting of the sugarcane. The harvesting mechanism of the harvesters is composed of a double rotary device with multiple blades that perform the cut by impact (Volpato, 2001). The cut of the culms should occur in an ideal way, avoiding the wear of the slides and ensuring the regrowth of the crop for next crops without decreasing the productivity (Voltarelli et al., 2014). The use of the mechanical cutting system may present some factors not favorable to the crop, specially the machine-plant interaction during the harvesting operation. This causes damages and shocks to the rootstock due to the contact with the base cutting discs, as well as visible losses such as splinters and incorporation of mineral material to culms when the disks touch the soil (Mello and Harris, 2003). Damage to rootstocks causes a higher incidence of diseases and fungi, since the injuries facilitate the entry of pathogens, negatively influencing the regrowth capacity (Malhães et al., 2013).

Similarly, cutting height is related to the base cutting system. The harvesters have a device that automatically controls the ideal cutting height according to the size and conditions of the cane field. This automatic adjustment of the base cut assists in the reduction in the amount of soil that reaches the industry due to the grinding wheels and according to losses of the stump (when the rootstocks stay above $5 \mathrm{~cm}$ from the ground), in the low consumption of fuel and in the reduction of damage to rootstocks (Ripoli et al., 2003).

Thus, the objective of this work is to evaluate the influence of speed at cutting height and the damage to the rootstock in function of mechanized harvesting of sugarcane.

\section{Results and discussion}

\section{Classification of damage to the rootstocks (\%)}

Table 1 shows the classification of damage to the rootstocks (\%) in function of the speed of movement of the sugarcane harvester $\left(\mathrm{km} \mathrm{h}^{-1}\right)$ for the evaluated treatments.

There was a difference among the rootstocks evaluated in the three speeds of displacement of the sugarcane harvester 
Table 1. Classification of damage to the rootstocks (\%).

\begin{tabular}{lllll}
\hline \multirow{2}{*}{ Speed $\left(\mathrm{km} \mathrm{h}^{-1}\right)$} & \multicolumn{5}{c}{ Scores (\%) } \\
\cline { 2 - 5 } & 1 & 2 & 3 & 4 \\
\hline V1 & 0.00 & 0.00 & 5.42 & 27.92 \\
V2 & 0.00 & 0.00 & 33.33 & 0.00 \\
V3 & 0.00 & 22.92 & 10.42 & 0.00 \\
\hline
\end{tabular}

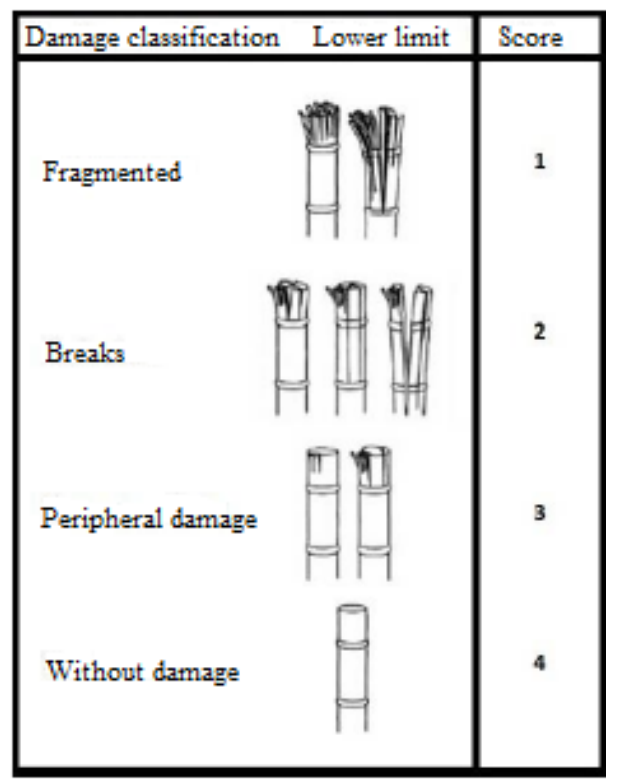

Fig 1. Damage on rootstocks. Source: Adapted from Kroes (1997), cited by Mello and Harris (2003).

Table 2. Mean of the cutting height of the rootstock $(\mathrm{cm})$.

\begin{tabular}{ll}
\hline Speed $\left(\mathrm{km} \mathrm{h}^{-1}\right)$ & Average cutting height $(\mathrm{cm})$ \\
\hline V1 & $2.62 \mathrm{C}$ \\
V2 & $3.56 \mathrm{~B}$ \\
V3 & $4.48 \mathrm{~A}$ \\
\hline ANOVA & \\
\hline F test (speed) & $\mathrm{CV}(\%)$ \\
$60.76^{*}$ & 23.67 \\
\hline sollowed by equal letters, upper case in columns, do not differ by Tukey test $(\alpha=5 \%), \mathrm{CV}$ - Coefficient of variation, ${ }^{*}$ significant at $5 \%$ probability.
\end{tabular}

$(p<0.01)$. We observed that at the highest speed $\left(7.0 \mathrm{~km} \mathrm{~h}^{-1}\right)$ (V3) (2), there was the highest percentage of rootstocks with breaks (score 2). However, in the other treatments the reduction of displacement speed increased the percentage of rootstocks with no damage (score 4), which can be observed at the speed $3.0 \mathrm{~km} \mathrm{~h}^{-1}$ (V1). The ideal cut was observed in intact rootstock and the stump had minimal damage (without damage, score 4) (Mello and Harris, 2001). The damage to rootstock caused an increased incidence of pests and diseases, removal of new buds responsible for sprouting, damage to the root system, and reducing yield of the next crop (Kroes and Harris, 1994). In addition to the speed of displacement, other factors may influence damage to rootstocks, such as cutting blade wear, work shift (day and night), soil moisture, positioning of rootstocks in relation to the furrow, among others. Noronha (2011), evaluated the day and night sugarcane mechanized harvesting at an average speed of $6.2 \mathrm{~km} \mathrm{~h}^{-1}$ and observed a significant difference regarding peripheral damages (score 3 ) caused to the rootstock between periods, with $42.6 \%$ in the daytime harvest and $35.8 \%$ in the evening harvest. As for fragmentation (score 1), $36.4 \%$ was obtained in the daytime harvest and $31.2 \%$ in the nighttime harvest. For desirable cut height when the sugar cane is at the bottom of the groove, the blades come in contact with the edges of the groove, increasing wear by abrasion, resulting in greater damage to the rootstock because there is rupture of the internodes rather than shear, which would be ideal (Volpato, 2001). However, according to Braunbeck and Magalhães (2009), when the cutting is performed with the blades above ground level, it reduces the start push and rootstock concussion, and there is less wear of the knives, since they have less contact with the soil. On the other hand, it increases losses because they leave larger stumps in the field.

\section{Cutting height}

The speed of movement of the harvester also interferes with the cutting height of the sugarcane (Table 2). As there was an increase in speed during the mechanized harvesting of sugarcane, the average height of cut also increased in the evaluated treatments, and the highest average height of cuts occurred at the speed of displacement V3 $\left(7.0 \mathrm{~km} \mathrm{~h}^{-1}\right)$, 
differing statistically from all other speeds at a 5\% probability level. This can be associated with an increase in the difficulty of the operator to maintain a lower cutting height due to the response time with the irregularities of the terrain, which can also occur in an automatic cutting height control system. The main issue involved in cutting height is plant losses, according to Noronha et al (2011), who reported that the variables stump loss and cut height are directly related, whereas the higher the height of the basal cut, the greater the stump height observed. However, Silva et al. (2008), studied tillering and productivity of sugarcane with different cutting heights and harvesting times. They found that, higher cutting height, reserves energy accumulation at the base of the stalks. In this case, the regrowth of sugarcane is favored. According to Salvi (2006), the impurity sent to the industry is related to the height of the base cut, because if the cutting height is too low and the blades come into contact with the soil, the level of mineral impurity sent to the industry will be higher. This relation does not only occur in losses and impurities, but also with rootstock pull out and reduced longevity of sugarcane plantations. Considering the importance of the base cut for the quality of the operation, the companies that manufacture harvesters have developed devices to aid in the control of cutting height (Cherubin, 2015).

\section{Materials and methods}

\section{Experimental characteristics}

The experiment was carried out in an area of sugarcane production in the state of São Paulo. The mechanized harvest was conducted without previous burning of the cane field, in an experimental area with a slope of $6 \%$ and a spacing of 1.5 meters between rows of planting. The variety used was CTC 15, with an average yield of $92.5 \mathrm{t} \mathrm{ha}^{-1}$.

\section{Treatments}

Throughout the experiment, the same harvester of a CASE A8800 manufacturing line was used with year of manufacture 2010, during the daytime harvest. The harvester had treadmill running and power of $243 \mathrm{~kW}$ engine. For the treatments, three speeds were selected to move the harvester: V1 was $3.0 \mathrm{~km} \mathrm{~h}^{-1}, \mathrm{~V} 2$ was $5.0 \mathrm{~km} \mathrm{~h}^{-1}$ and $V 3$ was $7.0 \mathrm{~km} \mathrm{~h}^{-1}$, and 4 replications were performed for each treatment with plots of 100 meters in length.

\section{Evaluations}

The evaluation of the quality of the mechanized harvest in relation to the basal cut was determined according to the methodology of Kroes (1997). The evaluation of the remaining stumps and the damages caused to rootstocks after the harvester were conducted according to Mello and Harris (2003), to which scores of 1 to 4 were attributed in function of the damage to each pile evaluated in the plots (Fig 1). For all treatments, the cutting blades of the harvester were new to avoid exerting any influence with respect to wear.

The cutting height of the rootstock was evaluated randomly after the sugar cane harvester passed using a tape measure in 80 rootstocks, performing 4 replications for each treatment.

\section{Statistical analysis}

The experimental design was completely randomized with three displacement speeds $\left(3.0,5.0\right.$ and $\left.7.0 \mathrm{~km} \mathrm{~h}^{-1}\right)$ and four replications. Statistical analysis was performed using the Minitab software (16). For the damages to rootstocks, the chi-square test was applied, the cut height was submitted to ANOVA and the averages were analyzed by the Tukey test at $5 \%$ probability.

\section{Conclusion}

The increase in the speed of displacement of the sugarcane harvester influenced the height of the cut and increased the damage to the rootstock. In addition, the least damage was observed at lowest harvesting speed. Table 2 has the highest cutting height at the highest harvest speed.

\section{References}

Braunbeck OA, Magalhães PSG (2009) A contribuição da FEAGRI-UNICAMP. In: Ripoli TCC, Ripoli MLC (Org.) Biomassa de cana-de-açúcar: colheita, energia e ambiente. 2. edn, Piracicaba, Brasil. 2.

Cherubin N. Corte mais preciso. In: http://revistarpanews.com.br/edicoes/176/Ed176web.pdf. Accessed in: 20 march 2018.

Companhia nacional de abastecimento (2018) Acompanhamento da safra brasileira: cana-de-açúcar, v. 3 - Safra 2016/17, n. 4 - Quarto levantamento, Brasília, p. 177, abril 2017. http://www.conab.gov.br/OlalaCMS/uploads/arquivos/17 _04_19_11_27_36_boletim_cana_portugues_-_4o_lev__16-17.pdf Accessed in: 08 feb. 2018.

Giachini CF, Ramos CRG, Lyra GA, Gamero CA, Lanças K (2016) Consumo de combustível e perdas de cana-deaçúcar durante a colheita diurna e noturna. Energ Agric. 31.

Kroes S, Harris HD (1994) Effects of cane harvester basecutter parameters on the quality of cut. Proceedings of Australian Society of Sugar Cane Technologists. 16:169177.

Manhães CMC, Garcia RF, Júnior DR, Francelino FMA, Júnior JFSA, Francelino HO (2013) Perdas quantitativas e danos às soqueiras na colheita de cana-de-açúcar no Norte Fluminense. Revista Vértices. 15:3.

Mello RC, Harris H (2001) Angled and serrated blades reduce damage, force and energy for a harvester basecutter. Proceedings of Australian Society of Sugar Cane Technologists. 123:212-218.

Mello RC, Harris H (2003) Desempenho de cortadores de base para colhedoras de cana-de-açúcar com lâminas serrilhadas e inclinadas. Agriambi. 7: 2.

Minitab. Minitab 16 Statistical Software ${ }^{\circledR}$. Minitab Inc., 2007. Noronha RHF, Silva RP, Chioderoli CA, Santos EP, Cassia MT (2011) Controle estatístico aplicado ao processo de colheita mecanizada diurna e noturna de cana-de-açúcar. Bragantia. 70: 4. 
Ripoli MLC, Ripoli TCC, Oliveira MA (2003) Evalution of two different base cutters in green cane mechanical harvest. Presented at ASAE annual international meeting, Las Vegas. 2003.

Salvi JV (2006) Qualidade do corte de base de colhedoras de cana-de-açúcar. 89 p. Dissertação (Mestrado em Agronomia) - Curso de pós-graduação em Agronomia, Universidade de São Paulo, Escola Superior de Agricultura "Luiz de Queiroz", Piracicaba.

Silva MA, Jeronimo EM, Lúcio AD (2008) Perfilhamento e produtividade de cana-de-açúcar com diferentes alturas de corte e épocas de colheita. Pesq Agropec Bras. 43:8.
Volpato JLM (2001) Otimização de um cortador de base flutuante para seguimento do perfil de solo em colhedoras de cana-de-açúcar. 204 p. Tese (Doutorado em Máquinas Agrícolas) - Faculdade de Engenharia Agrícola, Universidade Estadual de Campinas, Campinas.

Voltarelli M, Silva RP, Zerbato C, Holanda HV (2014) Corte de qualidade. Cultivar Máquinas. 146:18-19. 